\title{
Pergeseran Faktor Psikologi Penentu Keputusan Pembelian (Studi Kasus Sayuran Organik Di Pasar Modern Kota Palembang)
}

\section{Shifting Psychological Factors Determining Purchasing Decisions: A Case Study of Organic Vegetables in The Modern Market of Palembang City}

\author{
Yandri Ridho Pratama ${ }^{1}$, Dessy Adriani ${ }^{1 *}$, Laila Husin ${ }^{1}$ \\ ${ }^{1}$ Program Studi Agribisnis. Jurusan Sosial Ekonomi. Fakultas Pertanian. Universitas Sriwijaya. \\ Jalan Raya Palembang Prabumulih KM. 32 Indralaya-Ogan Ilir. 30662. \\ *E-mail : dessyadriani@fp.unsri.ac.id
}

\begin{abstract}
Abstract Increased awareness of the importance of health is also thought to have an impact on the consumption behavior of organic vegetables. So far, more research on purchasing decisions has been analyzed with consideration of microeconomic theory. Along with the development of information and knowledge, purchasing decisions are thought not only to be economic decisions but also to psychological considerations, especially the determinant factors. This research was carried out in the modern market of Palembang city. The research method was a survey method and the sampling method was an accidental sampling technique. Data analysis using Factorial Multivariate Analysis. The results of the analysis show psychological factors that influence purchasing decisions in terms of the importance level are (1) Perception, (2) Learning, (3) Attitudes, and (4) consistency. The analysis results differ with the level of theoretical importance. The level of importance based on the analysis are (1) motivation, (2) perception, (3) learning, and (4) attitude. The results of this study indicate that motivation is no longer a psychological factor in purchasing decisions, and there is a shift in factors where perception is the first and most important determining factor.
\end{abstract}

Keywords: consumption behavior, factors, level of importance

Disubmit : 4 April 2021, Diterima:12 Mei 2021, Disetujui : 26 Juli 2021

\section{PENDAHULUAN}

(Badan Pusat Statistik, 2018) mengemukakan bahwa tingkat konsumsi sayuran pada penduduk Indonesia pada tahun 2017 baru sebesar 34,55 kg/capital/tahun. Angka tersebut sangat jauh di bawah rekomendasi Food Agriculture Organization (FAO) sebesar 73 kg/capita/tahun di tahun yang sama. Adanya kebutuhan akan pola konsumsi sayuran di tingkat masyarakat di berbagai provinsi di Indonesia, membuat jumlah produksi harus dapat memenuhi kebutuhan pola konsumsi sayuran. Namun peningkatan kebutuhan konsumsi sayuran di berbagai wilayah masih harus dihadapkan dengan permasalahan keamanan produksi sayuran yang seringkali diikuti dengan penggunaan bahan kimia secara berlebihan dalam proses produksinya. Penggunaan bahan kimia tersebut pada umumnya adalah bahan beracun sehingga bila digunakan dapat meracuni tanah, tanaman, udara, air, lingkungan hidup lainnya, dan bahkan kesehatan manusia (Pracaya, 2002). Fakta tersebut tentu saja bertentangan dengan meningkatnya kesadaran masyarakat akan hidup sehat membuat peningkatan. Pola makan tinggi lemak, tinggi kalori dan rendah serat mulai ditinggalkan, diikuti peningkatan konsumsi makanan organik. Gejala positif ini perlu digalakkan lebih luas lagi, sehingga untuk 
tujuan tersebut diperlukan pengetahuan dan kesadaran diri yang baik untuk merubah gaya konsumsi (Rifai et al, 2008).

Saat ini permintaan pangan organik (PO) mengalami peningkatan yang sangat pesat di seluruh dunia yakni meningkat sekitar 20\% per tahun sehingga permintaan tersebut mampu menciptakan pasar potensial bagi produk-produk organik (Deliana, 2012). Di Indonesia pasar produk organik mengalami perkembangan signifikan. Hal tersebut bisa dilihat dengan adanya peningkatan luas lahan pertanian organik setiap tahunnya yang diteliti oleh (Organic Institute, 2019), yang ditunjukan pada Gambar 1.

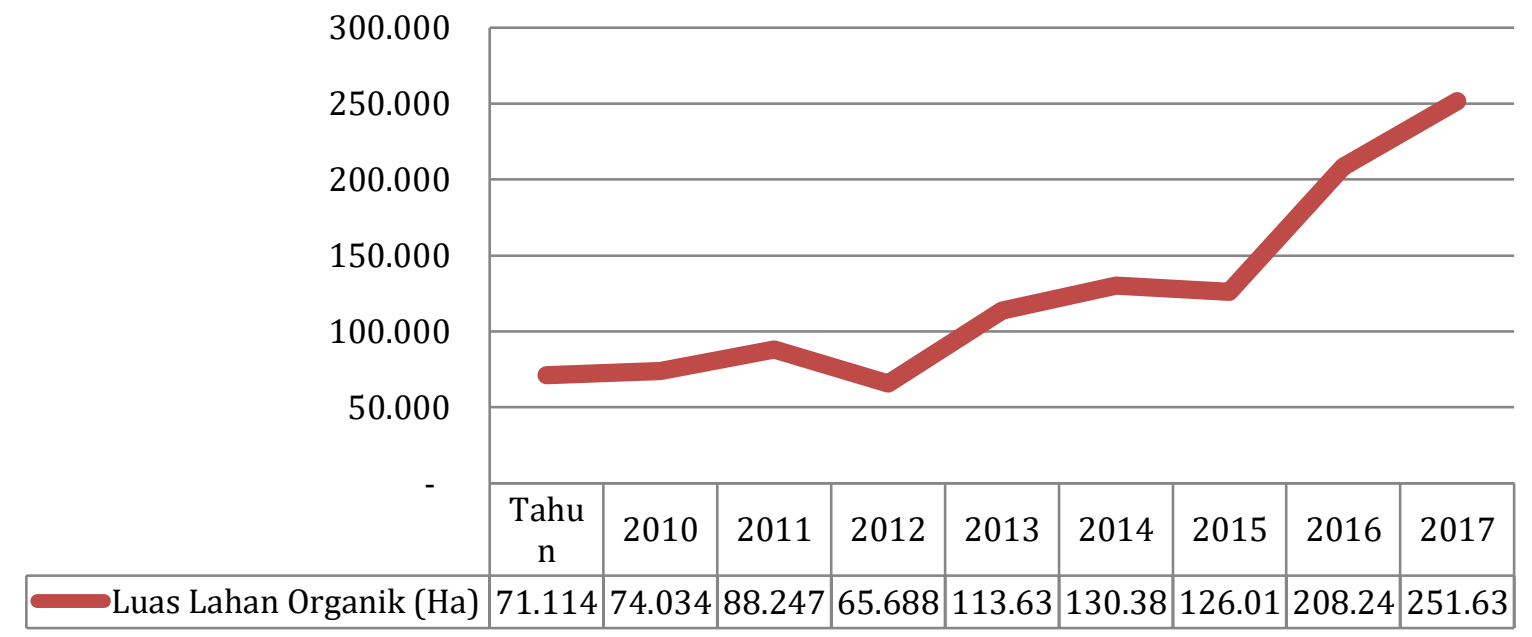

Sumber: Organic Institute, 2019

Gambar 1. Luas Lahan Organik di Indonesia, 2010-2018

Sayuran organik merupakan produk organik yang paling banyak di konsumsi oleh masyarakat) (Deliana, 2012) (Organic Institute, 2019) Hal ini juga didukung oleh pertambahan luas lahan sayuran organik setiap tahun pada tahun 2010-2018 (Kardinan, 2016) (Organic Institute, 2019) . Gambar 2 menyajikan luasan produksi sayuran organik setiap tahun.

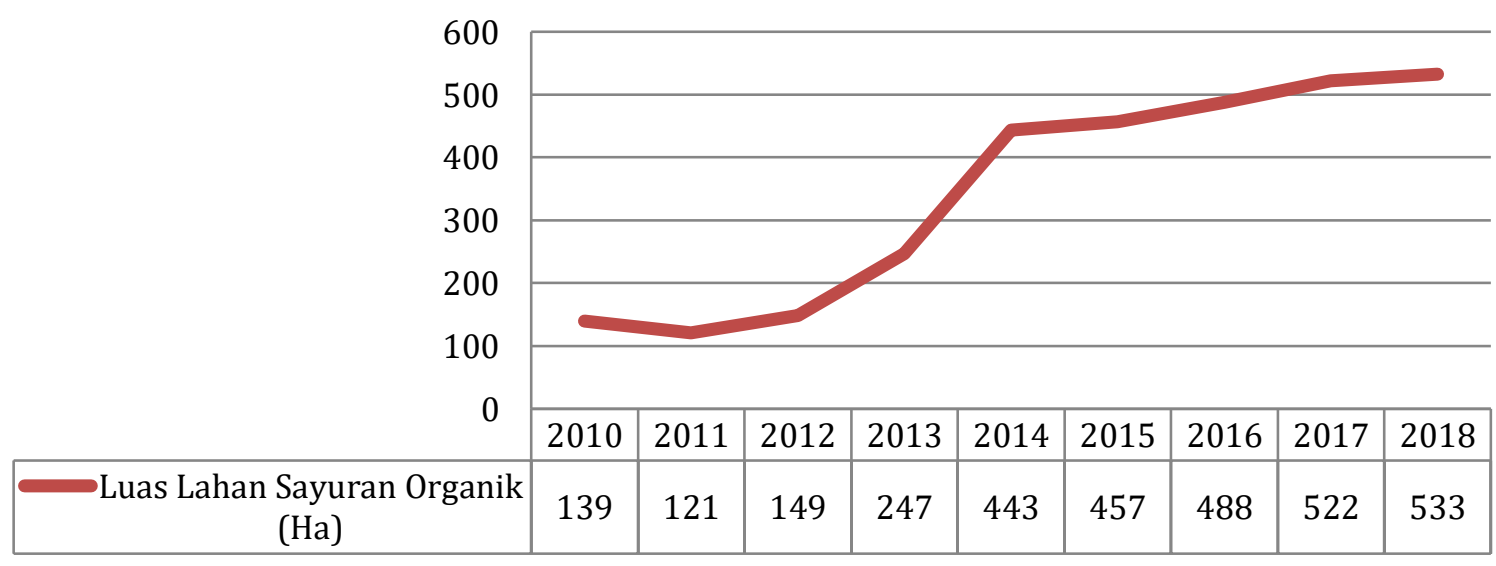

Sumber: Organic Institute, 2019

Gambar 2. Perkembangan Luas Sayuran Organik, 2010-2018

Provinsi Sumatera Selatan merupakan salah satu daerah pertanian yang mengusahakan tanaman pangan dan hortikultura termasuk sayuran. Di Sumatera Selatan, produktivitas sayuran dari Kota Pagaralam memiliki produktivitas paling tinggi yaitu $68,83 \mathrm{kuintal} / \mathrm{ha}$ pada tahun 2017, sementara produktifitas yang paling rendah adalah di Kota Palembang yaitu 0,92 kuintal/ha. Di saat yang sama, sementara Kota Palembang merupakan 
kota dengan jumlah penduduk terbesar di Sumatera Selatan yang memiliki jumlah konsumsi sayuran yang paling tinggi. Kota Palembang memiliki jumlah penduduk terbesar di Sumatera Selatan yaitu 1.558.494 jiwa dengan luas daerah 374,03 km2 dan kepadatan penduduk sebesar 4.166,76 jiwa/ km2. Hal ini menjadikan Kota Palembang sebagai salah satu sasaran produsen sayuran baik bagi sayuran organik maupun sayuran anorganik.

Sayuran organik adalah sayuran yang dibudidayakan dengan teknik pertanian yang mengandalkan bahan-bahan alami tanpa bahan-bahan kimia sintetis. Tujuan utama sayuran organik adalah menyediakan produk pertanian bahan pangan yang aman bagi kesehatan produsen dan konsumen serta tidak merusak lingkungan. Sayuran organik sebagai bagian dari pertanian yang akrab dengan lingkungan perlu segera dimasyarakatkan sejalan makin banyaknya dampak negatif terhadap lingkungan yang terjadi akibat dari penerapan teknologi intensifikasi yang mengandalkan bahan kimia pertanian (Muchtadi, 2001) (Kardinan, 2016) .

Konsumsi sayuran pada Kota Palembang sudah semakin meningkat. Berbagai jenis sayuran yang mudah dijumpai di pasar tradisional, supermarket, warung dan lain-lain membuat bisnis sayuran juga mendapatkan potensi yang baik. Selain sayuran anorganik yang sudah lama beredar di masyarakat kota Palembang, sayuran organik pun sudah muncul di Kota Palembang. Kesadaran masyarakat akan memperoleh produk pertanian yang segar, aman serta sehat dipasaran membuat beberapa pengusaha menghadirkan sayuran organik di Kota Palembang. Saat ini sayuran organik sudah mulai banyak dijual di beberapa lokasi di Kota Palembang, terutama pada pasar modern di Kota Palembang. Riset-riset mengenai perilaku konsumen sayuran organic belum banyak dilakukan di Kota Palembang, sehingga sumber pustaka menjadi terbatas.

Peningkatan permintaan sayuran organik di Kota Palembang, bila merujuk pada teori, tentunya dipengaruhi oleh perilaku konsumen. Banyak faktor yang mempengaruhi perilaku konsumsi sayuran organik. Menurut teori perilaku konsumen, faktor ekonomi, yaitu harga dan pendapatan, merupakan faktor utama yang mempengaruhi keputusan pembelian konsumen. Menurut hasil penelitian (Utari, 2014), keputusan konsumen dalam membeli atau mengkonumsi barang atau jasa dipengaruhi oleh: (1) perbedaan dan pengaruh individu, (2) pengaruh lingkungan dan pengaruh psikologi. Lebih lanjut, menurut (Basu S and Handoko, 1987), dalam mengetahui, memahami dan mengarahkan perilaku konsumen untuk melakukan kegiatan pembelian, maka setiap riset tidak hanya melibatkan teori-teori perilaku konsumen seperti teori ekonomi mikro, tetapi juga mempertimbangan teori psikologis, teori sosiologis dan teori antropologis dalam analisisnya. (Jaolis, 2011) (Suardika et al, 2014) dan (Sutarni et al, 2017) menyatakan faktor penentu penting dalam pembelian produk pertanian organik adalah sertifikat, ketersediaan, kemasan dan harga. Aspek internal yang terdiri dari motivasi, pembelajaran, dan pengaruh sikap positif dan sangat signifikan terhadap keputusan pembelian sayuran organik, namun persepsi, promosi dan lokasi berpengaruh tidak berpengaruh signifikan terhadap keputusan pembelian sayuran organik.

(Afandy et al, 2014) dan (Latif, 2011) menyatakan keputusan pembelian merupakan hasil perhitungan ekonomis dan rasional. Banyak teori konsumsi yang menganalisis keputusan pembelian hanya memperhatikan faktor-faktor ekonomi, meninggalkan faktor psikologis dan sosilogis yang sebenarnya juga dapat mempengaruhi perilaku konsumen tidak termasuk dalam model teori tersebut. Menurut Basu dan (Basu S dan Handoko, 1987) serta (Kotler dan Keller, 2009), faktor penentu psokologis secara teori berdasarkan urutan kepentingannya adalah (1) Motivasi, (2) persepsi, (3) pembelajaran dan (4) sikap. Makin berkembang dan beragamnya perilaku konsumen akibat perubahan pendidikan, pekerjaan, status sosial, dan faktor lainnya diduga menyebabkan terjadinya perubahan tingkat kepentingan faktor tersebut. Dengan kata kali, diduga terjadinya pergeseran faktor dalam keputusan pembelian tersebut. Oleh karena itu, penelitian ini bertujuan untuk mengindentifikasi terjadinya pergeseran faktor psikologis penentu keputusan pembelian sayuran organik di pasar modern Kota Palembang. Pemahaman yang terintegrasi atas berbagai aspek terkait perilaku konsumen akan memudahkan pemasar menyusun strategi pemasaran. 


\section{METODE PENELITIAN}

Pembentukan Model Penelitian. Teori psikologis didasarkan pada faktor-faktor psikologis individu yang selalu dipengaruhi oleh kekuatan-kekuatan lingkungan. Pada prinsipnya teori ini merupakan penerapan dari teori-teori dalam bidang psikologis dalam menganalisis perilaku konsumen. Teori ini menyatakan pada keputusan akan dipengaruhi oleh empat komponen yaitu dorongan, petunjuk, tanggapan, penguatan. Teori ini menekankan bahwa penafsiran dan permasalahan terhadap proses belajar konsumen merupakan kunci untuk mengetahui perilaku pembelinya. Kekuatan-kekuatan psikologi yang membentuk perilaku pembeli sebagian besar berasal dari bawah sadar (Kotler dan Keller, 2009).

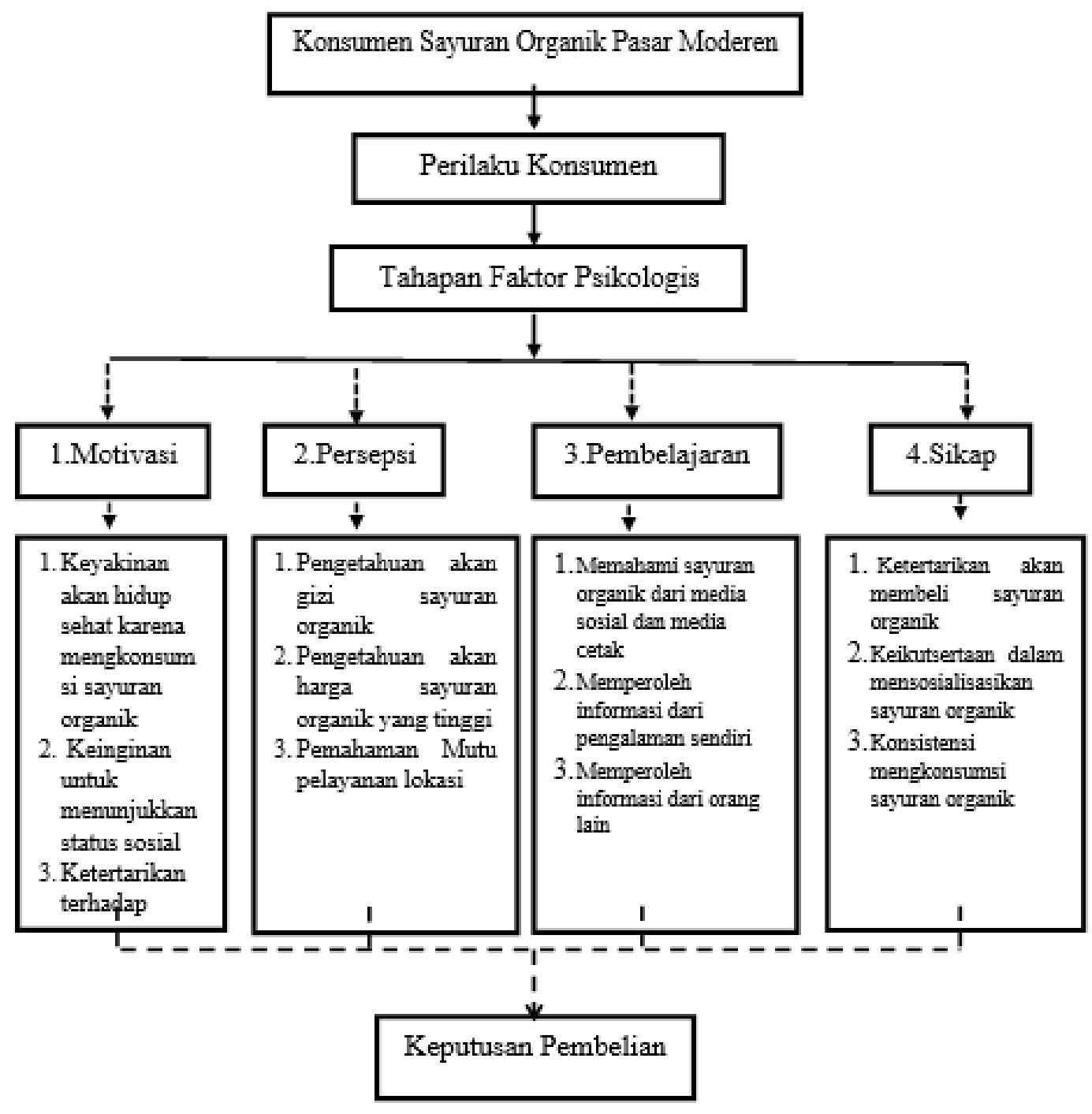

Gambar 3. Model Pendekatan Penelitian

Tahapan awal dalam perilaku konsumsi adalah munculnya motivasi untuk mengkonsumsi. Perilaku sesorang dimulai dengan adanya insiati motif yang menggerakan individu dalam mencapai suatu tujuan. Secara definisi motivasi adalah suatu dorongan kebutuhan dan keinginan individu yang diarahkan pada tujuan untuk memperoleh kepuasaan (Basu S dan Handoko, 1987). Tiga dari teori-teori motivasi manusia yang terkenal adalah teori Sigmun Freud, Abraham Maslow dan Frederic Herberg (Kotler dan Keller, 2009). (Sunyoto, 2014) menyatakan bahwa ada 2 tipe motivasi, yaitu motivasi rasional (penilaian produk berdasarkan objektivitas) dan motivasi emosional (penilaian produk berdasarkan subjektivitas). Tanpa motivasi seseorang tidak akan terpengaruh untuk mencari kepuasaan terhadap dirinya. Para ahli psikologis telah mengembangkan teori-teori motivasi manusia. 
Tahapan ke-dua adalah proses pembentukan persepsi. isepipipersepsi didefiniskan sebagai proses dimana seseorang memilih, mengorganisasikan dan mengartikan masukan informasi untuk cipatakan suatu gambaran yang berarti dari dunia ini (Kotler dan Keller, 2009). Lain halnya dengan (Schiffman dan Kanuk, 2008) berpendapat bahwa persepsi didefinisikan sebagai proses yang dilakukan individu untuk memilih, mengatur, dan menafsirkan stimuli ke dalam gambar yang berarti dan masuk akal mengenai dunia. persepsi dapat melibatkan penafsiran seseorang atas suatu kejadian berdasarkan pengalaman masa lalunya. Pada pemasar perlu bekerja keras untuk memikat perhatian konsumen agar pesan yang disampaikan dapat mengenai pada sasaran.

Tahapan ke-tiga adalah proses pembelajaran (learning) mendorong perubahan dalam perilaku seseorang yang timbul dari pengalaman (Kotler dan Keller, 2009). Perubahan-perubahan perilaku tersebut bersifat tetap dan fleksibel. Hasil belajar ini akan memberikan tanggapan tertentu. Perilaku yang dipelajari tidak hanya menyangkut perilaku yang tampak tetapi juga menyangkut sikap, emosi, kepribadian, kriteria penilaian dan banyak faktor lain yang tidak dapat ditunjukkan dengan kegiatan-kegiatan yang tampak. Proses pembelajaran terjadi karena adanya interaksi antara manusia yang dasarnya bersifat individual dengan lingkungan khusus tertentu. Proses belajar pada suatu pembelian terjadi apabila konsumen ingin menanggapi dan memperoleh suatu kepuasan, atau sebaliknya tidak terjadi apabila konsumen merasa dikecewakan oleh produk yang kurang baik (Rifai et al, 2008) (Sunyoto, 2014)

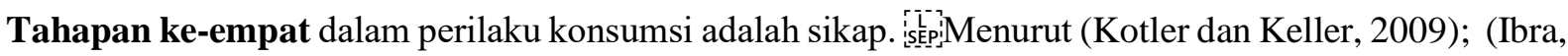
2017) perubahan sikap (attitude), yaitu evaluasi dalam waktu lama tentang yang disukai atau tidak disukai seseorang perasaan emosional, dan kecenderungan tindakan terhadap beberapa objek atau ide. Sikap menempatkan seseorang dalam kerangka pikiran: menyukai atau tidak menyukai sebuah objek, bergerak menuju atau beralih darinya. Tahapan lengkap dari proses tersebut disajiakan dalam Gambar 2. Dalam model pendekatan penelitian di atas, urutan faktor menunjukkan peringkat kepentingan faktor. Motivasi menjadi faktor pertama, karena berdasarkan teori psiokologi motivasi merupakan perilaku awal penentu konsumen untuk mengkonsumsi, dilanjutkan dengan faktor pembentukan persepsi, pembelajaran, dan perubahan sikap.

Metode penelitian adalah metode survey. Penelitian ini akan dilaksanakan di Kota Palembang yaitu Supermarket Diamond yang berada dalam kawasan supermarket Palembang Trade Center. Penentuan lokasi ini dilakukan dengan sengaja (purposive). Dalam penelitian ini, jumlah populasi yang mengkonsumsi sayuran organik tidak diketahui. Populasi seperti ini secara statistik disebut populasi tidak terbatas. Untuk populasi yang tidak terbatas, maka pengampilan sampel menggunakan nonprababilty sampling dengan tehnik pengambilan sampel secara sengaja (accidental sampling technique). Sampel yang sesuai dengan kerangka sampling akan diambil sebagai sampel. Kerangka samplingnya adalah pelanggan yang pernah membeli sayuran organik di pasar modern. Dalam menentukan jumlah sampel digunakan $Z=90 \%$ (tingkat kepercayaan 90\%), $p=50 \%$ (proporsi contoh 50\%) serta $e=15 \%$ (sampling error 15\%) diperoleh sampel sebanyak 30 orang (Arikunto, 2013).

Metode pengumpulan data yang digunakan dalam penelitian ini adalah wancarara terstruktur dengan panduan kuesioner. Adapun pengukuran yang digunakan pada penelitian ini adalah skala Likert. Variabel yang akan diukur dijabarkan menjadi indikator variabel. Lalu indikator akan dijadikan titik tolak yang digunakan untuk menyusun item-item instrumen yang bisa berupa pertanyaan-pertanyaan. Pada penelitian ini skala Likert menggunakan pernyataan positif dimana skornya adalah dari SS sampai STS adalah 5-1. Skala Likert memiliki gradasi dari sangat negatif sampai dengan sangat positif yang dapat berupa kata-kata sebagai berikut: SS = Sangat Setuju (5); ST = Setuju (4); RG = Netral (3); TS = Tidak Setuju (2); STS = Sangat Tidak Setuju (1).

Metode pengolahan data yang digunakan untuk menjawab penelitian menggunakan Analisis Faktorial. Menurut (Firdaus et al, 2013) dan (Riyanto dan Agus, 2012) Tahapan dalam analisis multivariat sebagai berikut: 
a. Uji Validitas dengan menggunakan teknik korelasi Product Moment Pearson

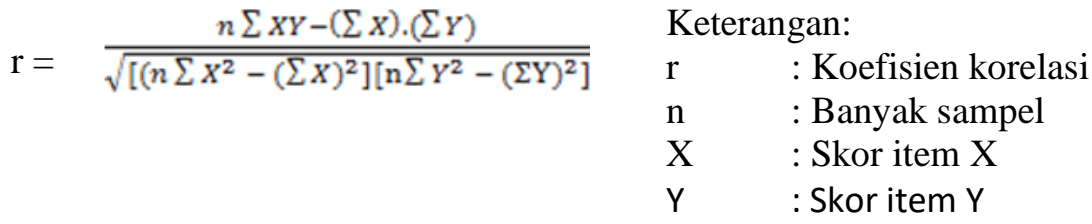

Suatu butir instrument yang valid dapat diketanuı apabıla nılaı koetısıen korelasi sama dengan atau lebih besar dari $r$ tabel ( $r \geq r$ tabel) sebagai nilai kritisnya. Sebaliknya, jika kurang dari $r$ tabel maka dinyatakan tidak valid .

b. Uji Reliabilitas dengan menggunakan koefisen Alpha atau disebut Alpha Cronbach. Rumus koefisien Alpha digunakan untuk mencari reliabilitas instrument yang skornya bukan 1 dan 0 , misalnya kuesioner. Rumus Alpha Cronbach adalah sebagai berikut:

$$
\begin{aligned}
& \mathrm{r}=\left[\frac{k}{k-1}\right]\left\lfloor 1-\frac{\sum \mathrm{S}_{i}}{\mathrm{~S}_{t}}\right\rfloor \quad \text { Keterangan: } \\
& \mathrm{r} \quad \text { : Reliabilitas instrument } \\
& \text { k : Banyak butir pertanyaan } \\
& \Sigma \mathrm{S}_{i} \quad \text { : Jumlah varians butir } \\
& \mathrm{S}_{\mathrm{L}} \quad \text { : Varians total }
\end{aligned}
$$

Uji ini digunakan metode Alpha Cronbach yaitu dengan membandingkan koefisien alphan dengan $\mathrm{r}$ tabel. Jika koefisien alpha ( $\mathrm{r}$ hitung $\geq \mathrm{r}$ tabel maka butir tersebut reliabel. Jika koefisien alpha $(\mathrm{r}$ hitung) $<\mathrm{r}$ tabel maka butir tersebut tidak reliable. Instrumen dapat dikatakan reliabel bila memiliki koefisien reliabilitas $r$ tabel atau lebih.

\section{c. Analisis Faktor}

(Ariastuti dan Made, 2008)menjelaskan tahapan-tahapan dari penggunaan analisis faktor adalah sebagai berikut

1) Merumuskan masalah dimana variabel-variabel yang akan dipilih adalah variabel yang relevan dengan penelitian yang dilakukan dan harus didasarkan pada penelitian-penelitian terdahulu, teori, dan pendapat peneliti sendiri.

2) Membuat matriks korelasi yang berkenaan dengan analisis faktor, pengujian yang harus dilakukan, yaitu :

a. Barlett's Test of Spercity dipakai untuk menguji bahwa variabel-variabel dalam sampel berkorelasi

b. Uji Kaise-Meyer-Olkin (KMO) yang digunakan untuk mengetahui kecukupan sampel atau pengukuran kelayakn sampel. Analisis fakroe dianggap layak jika besaran KMO > 0,5

c. Uji Measure of Sampling Adequency (MSA) digunakan untuk mengukur derajat korelasi antar variabel dengan kriteria MSA > 0,5

3) Menentukan ketepatan model dimana tahap ini bertujuan untuk mengetahui apakah model mampu menjelaskan dengan baik fenomena yang ada. Hal tersebut bisa dilakukan dengan melihat jumlah residual antara korelasi yang diamati dengan korelasi yang direproduksi.

4) Menentukan jumlah faktor dimana penentuan jumlah faktor didasarkan pada besarnya eigen value setiap faktor yang muncul. Faktor-faktor inti yang dipilih adalah faktor yang memiliki eigen value $>1$.

5) Rotasi Faktor dilakukan untuk mempermudah interprestasi dalam menentukan variabel-variabel mana saja yang tercantum dalam suatu faktor karena terkadang ada beberapa variabel yang 
mempunyai korelasi tinggi dengan lebih dari satu faktor atau jika sebagian Factor Loading dari variabel bernilai di bawah terkecil yang telah ditetapkan.

6) Interprestasi Faktor dilakukan dengan cara mengelompokkan variabel yang mempunyai factor loading yang tinggi ke dalam faktor tersebut.

7) Penamaan faktor dimana penamaan faktor dilakukan setelah didapatkan loading factor yang dilihat pada indikator. Penamaan Faktor awal berdasarkan teori disajikan dalam Tabel 1.

Tabel 1. Penamaan Variabel, Indikator Penelitian, Skala Pengukuran dan Nilai Pengukuran

\begin{tabular}{|c|c|c|c|c|c|}
\hline No. & $\begin{array}{c}\text { Variabe } \\
1\end{array}$ & Pernyataan Indikator & $\begin{array}{c}\text { Penamaa } \\
n \\
\text { Indikator }\end{array}$ & $\begin{array}{c}\text { Skala } \\
\text { Pengukur } \\
\text { an }\end{array}$ & Nilai Pengukuran \\
\hline \multirow{3}{*}{1} & \multirow{3}{*}{$\begin{array}{c}\text { Motiva } \\
\text { si } \\
\left(\mathrm{X}_{1}\right)\end{array}$} & $\begin{array}{l}\text { Keyakinan akan hidup sehat karena konsumsi } \\
\text { sayuran organik }\end{array}$ & $\mathrm{X}_{1,1}$ & & \multirow{12}{*}{$\begin{array}{l}\text { SS = Sangat Setuju (5); } \\
\text { ST = Setuju (4); } \\
\text { RG = Netral (3); } \\
\text { TS = Tidak Setuju (2); } \\
\text { STS = Sangat Tidak } \\
\text { Setuju (1).k }\end{array}$} \\
\hline & & Keinginan untuk menunjukkan status sosial & $\mathrm{X}_{1,2}$ & & \\
\hline & & Ketertarikan terhadap kualitas sayuran organik & $\mathrm{X}_{1,3}$ & & \\
\hline \multirow{3}{*}{2} & \multirow{3}{*}{$\begin{array}{l}\text { Perseps } \\
\quad \mathrm{i} \\
\left(\mathrm{X}_{2}\right)\end{array}$} & Pengetahuan akan gizi sayuran organik & $\mathrm{X}_{2,1}$ & & \\
\hline & & $\begin{array}{l}\text { Pengetahuan akan harga sayuran organik yang } \\
\text { tinggi }\end{array}$ & $\mathrm{X}_{2,2}$ & & \\
\hline & & Pemahaman mutu pelayanan lokasi & $\mathrm{X}_{2,3}$ & Ordinal & \\
\hline \multirow{3}{*}{3} & \multirow{4}{*}{$\begin{array}{c}\text { Pembel } \\
\text { ajaran } \\
\left(\mathrm{X}_{3}\right)\end{array}$} & $\begin{array}{l}\text { Memahami sayuran organik dari media sosial } \\
\text { dan media cetak }\end{array}$ & $\mathrm{X}_{3,1}$ & Ordinal & \\
\hline & & Memperoleh informasi dari pengalaman sendiri & $\mathrm{X}_{3,2}$ & & \\
\hline & & Memperoleh informasi dari orang lain & $X_{3,3}$ & & \\
\hline \multirow{3}{*}{4} & & Ketertarikan akan membeli sayuran organik & $\mathrm{X}_{4,1}$ & & \\
\hline & \multirow[t]{2}{*}{$\begin{array}{c}\text { Sikap } \\
\left(\mathrm{X}_{4}\right)\end{array}$} & $\begin{array}{l}\text { Keikutsertaan dalam mensosialisasikan sayuran } \\
\text { organik }\end{array}$ & $\mathrm{X}_{4,2}$ & & \\
\hline & & Konsistensi mengkonsumsi sayuran organik & $X_{4,3}$ & & \\
\hline
\end{tabular}

\section{HASIL DAN PEMBAHASAN}

Karakteristik Responden. Berdasarkan Tabel 2 diketahui usia responden yang paling banyak membeli sayuran organik adalah pada rentang usia separuh baya (36-50 tahun) dengan persentase $40 \%$, sedangkan yang memiliki persentase terendah adalah pada rentang usia lanjut usia ( $>65$ tahun) sebanyak 1 orang dengan persentase 3,3\%, dan tidak ditemukan responden yang berusia remaja lanjut untuk membeli sayuran organik. Berdasarkan jenis kelamin, responden yang membeli sayuran organik terdiri dari 11 orang pria dengan persentase $36,7 \%$ dan 19 orang perempuan dengan persentase $63,7 \%$, responden yang membeli sayuran organik di pasar modern terbanyak adalah perempuan. Berdasarkan pendapatan, konsumsi sayuran organic berada pada persentase pendapatan tertinggi berada pada kisaran Rp. 2.500.000- 5.000.000 dan lebih dari Rp.5.000.000 yang masing-masing berjumlah 14 orang dengan persentase 46,7\%. Sisi profesi, persentase tertingi membeli sayuran organik adalah Pegawai Swasta/BUMN sebanyak 14 orang dengan persentase 46,7 $\%$, sedangkan yang terendah adalah persentase dari wiraswasta dan pelajar/mahasiswa masing-masing 1 orang dengan persentase $3,3 \%$. Berdasarkan status pernikahan, responden berstatus menikah yang mengkonsumsi sayur organik sebanyak 26 orang dengan persentase $86,7 \%$, sementara sisanya yaitu sebanyak 4 orang atau $13,3 \%$ masih lajang. Persentase tertinggi responden yang membeli sayuran organik adalah responden yang memiliki jumlah anggota keluarga sebanyak 3-5 orang persentase $83,8 \%$. Hal ini menunjukkan bahwa jumlah tanggungan jumlah yang sedikit akan mempengaruhi jumlah tingkat konsumsi.

Tabel 2 juga menunjukkan bahwa terdapat 5 sayuran organic yang paling banyak dikonsumsi yaitu selada, pokcoy-baby pokcoy, tomat brokoli dan kangkung. Sayuran organic yang paling banyak dibeli adalah selasa sebanyak 30,00\% responden dan pokcoy-baby pokcoy sebanyak 26, $3 \%$. Dari sisi frekuensi pembelian, 
sebanyak 43, $3 \%$ responden membeli sayuran organik antara 3-4 kali perbulan, 26,7 \% responden membeli sayuran organik antara 5-6 kali perbulan, serta 23,3\% membeli sayuran organik antara 1-2 kali perbulan.

Tabel 2. Karakteristik Responden

\begin{tabular}{|c|c|c|c|}
\hline No. & Kategori & Jumlah $(\mathbf{n}=\mathbf{3 0})$ & Persentase (\%) \\
\hline \multicolumn{4}{|c|}{ Usia (Tahun) } \\
\hline 1. & Remaja Lanjut (15-18) & 0 & 0 \\
\hline 2. & Dewasa Awal (19-24) & 2 & 6,7 \\
\hline 3. & Dewasa Lanjut (25-35) & 11 & 36,7 \\
\hline 4. & Separuh Baya (36-50) & 12 & 40 \\
\hline 5. & Tua dan Lanjut Usia (51- > 65) & 5 & 16,6 \\
\hline \multicolumn{4}{|c|}{ Jenis Kelamin } \\
\hline 1. & Pria & 11 & 36,7 \\
\hline 2. & Perempuan & 19 & 63,3 \\
\hline \multicolumn{4}{|c|}{ Pendidikan } \\
\hline 1. & SMA & 4 & 13,3 \\
\hline 2. & Diploma 3 & 1 & 3,4 \\
\hline 3. & Sarjana & 21 & 70 \\
\hline 4. & Pasca Sarjana & 4 & 13,3 \\
\hline \multicolumn{4}{|c|}{ Pendapatan Rumah Tangga (Rp/Bulan) } \\
\hline & $500.001-1.000 .000$ & 1 & 3,3 \\
\hline 2. & $1.000 .001-2.500 .000$ & 1 & 3,3 \\
\hline 3. & $2.500 .001-5.000 .000$ & 14 & 46,7 \\
\hline 4. & $>5.000 .001$ & 14 & 46,7 \\
\hline \multicolumn{4}{|c|}{ Profesi } \\
\hline & Ibu Rumah Tangga & 8 & 26,7 \\
\hline 2. & PNS & 6 & 20 \\
\hline & Pegawai Swasta/BUMN & 14 & 46,7 \\
\hline 4. & Wiraswasta & 1 & 3,3 \\
\hline & Pelajar/Mahasiswa & 1 & 3,3 \\
\hline \multicolumn{4}{|c|}{ Status Pernikahan } \\
\hline 1. & Menikah & 26 & 86,7 \\
\hline & Lajang & 4 & 13,3 \\
\hline \multicolumn{4}{|c|}{ Jumlah Anggota keluarga (orang) } \\
\hline 1. & $<2$ & 3 & 10 \\
\hline 2. & $3-5$ & 25 & 83,3 \\
\hline 3. & $6-8$ & 2 & 6,7 \\
\hline \multicolumn{4}{|c|}{$\begin{array}{l}\text { Jenis sayuran organik yang paling dikonsumsi } \\
\end{array}$} \\
\hline 1. & Pokcoy dan Baby Pokcoy & 8 & 26.67 \\
\hline & Selada & 9 & 30.00 \\
\hline 3. & Tomat & 5 & 16.67 \\
\hline & Kangkung & 2 & 6.67 \\
\hline & Brokoli & 5 & 16.67 \\
\hline & Lainnya & 1 & 3.33 \\
\hline \multicolumn{4}{|c|}{ Frekuwensi Pembelian Jenis sayuran organik Perbulan (Kali/bulan) } \\
\hline & $1-2$ & 8 & 26.67 \\
\hline & $3-4$ & 13 & 43.33 \\
\hline & $5-6$ & 7 & 23.33 \\
\hline & $>6$ & 2 & 6.67 \\
\hline
\end{tabular}


Gambaran Sayur Organik yang Dijual. Di lokasi penelitian terdapat beberapa sayuran organik yang dijual. Sayuran organik merupakan objek dari penelitian ini. Sayuran organik yang dijual di lokasi penelitian ada berbagai macam jenis yang dikeluarkan oleh 2 (dua) perusahaan Taniku dan Organik Living. Pada merk Taniku sayuran organik dengan penjualan tertinggi adalah sayuran Lettuce Romaine atau selada sebesar $89 \mathrm{~kg}$ perbulan, , penjualan kedua tertinggi adalah sayuran sayuran Baby pakcoy sebesar $76 \mathrm{~kg}$ perbulan, penjualan ketiga tertinggi adalah sayuran tomat sebesar $70 \mathrm{~kg}$ perbulan, dan penjualan terendah sayuran kangkung dan pagoda sebesar $30 \mathrm{~kg}$ perbulan. Pada Merk Organik Living sayuran organik penjualan adalah brokoli sebesar $374,06 \mathrm{~kg}$ perbulan.

Analisis Data. Uji Validitas dan Uji Reliabilitas. Uji validitas adalah uji ketepatan suatu alat ukur dalam mengukur apa yang sedang ingin diukur dalam suatu penelitian. Tujuan dari uji validitas adalah menilai apakah seperangkat alat ukur sudah tepat mengukur suatu nilai yang sedang diukur. Jika didapatkan koefisien korelasi yaitu r tabel dengan skor 28 mendapatkan hasil $\geq 0,374$ berarti instrument yang digunakan sudah valid. Uji validitas yang telah dilaksanakan dapat dilihat pada Tabel 3.

Berdasarkan data dari Tabel 3 diketahui bahwa semua koefisien korelasi memenuhi syarat yaitu memiliki nilai $r$ tabel $\geq 0,374$ dengan tingkat signifikansi adalah $\leq 0,5$. Variabel Motivasi $\left(X_{1}\right)$ memiliki indikator $\mathrm{X}_{1,1}$ dengan $\mathrm{r}$ hitung sebesar 0,676 dan memiliki tingkat signifikansi sebesar 0,000 . Indikator $\mathrm{X}_{1,2}$ dengan $r$ hitung sebesar 0,750 dan memiliki tingkat signifikansi sebesar 0,000. Indikator $X_{1,3}$ dengan $r$ hitung sebesar 0,800 dan memiliki tingkat signifikansi sebesar 0,000. Semua indikator pada variabel Motivasi $\left(\mathrm{X}_{1}\right)$ adalah valid.

Variabel Persepsi $\left(\mathrm{X}_{2}\right)$ memiliki indikator $\mathrm{X}_{2,1}$ dengan $\mathrm{r}$ hitung sebesar 0,828 dan memiliki tingkat signifikansi sebesar 0,000 . Indikator $\mathrm{X}_{2,2}$ dengan $\mathrm{r}$ hitung sebesar 0,681 dan memiliki tingkat signifikansi sebesar 0,000. Indikator $\mathrm{X}_{2,3}$ dengan $\mathrm{r}$ hitung sebesar 0,730 dan memiliki tingkat signifikansi sebesar 0,000. Semua indikator pada variabel Persepsi $\left(\mathrm{X}_{2}\right)$ adalah valid.

Indikator $\mathrm{X}_{3,1}$ dengan $\mathrm{r}$ hitung sebesar 0,475 dan memiliki tingkat signifikansi sebesar 0,000. Indikator $X_{3,2}$ dengan $r$ hitung sebesar 0,706 dan memiliki tingkat signifikansi sebesar 0,000 . Indikator $X_{3,3}$ dengan $r$ hitung sebesar 0,809 dan memiliki tingkat signifikansi sebesar 0,000. Semua indikator pada variabel Pembelajaran $\left(\mathrm{X}_{3}\right)$ adalah valid.

Indikator $\mathrm{X} 4,1$ dengan $\mathrm{r}$ hitung sebesar 0,856 dan memiliki tingkat signifikansi sebesar 0,000. Indikator $\mathrm{X}_{4,2}$ dengan $\mathrm{r}$ hitung sebesar 0,790 dan memiliki tingkat signifikansi sebesar 0,000 . Indikator $\mathrm{X}_{4,3}$ dengan $\mathrm{r}$ hitung sebesar 0,656 dan memiliki tingkat signifikansi sebesar 0,000. Semua indikator pada variabel sikap $\left(\mathrm{X}_{4}\right)$ adalah valid.

Dengan demikian, dapat disimpulkan bahwa seluruh indikator yang ada di variabel motivasi $\left(\mathrm{X}_{1}\right)$, persepsi $\left(\mathrm{X}_{2}\right)$, pembelajaran $\left(\mathrm{X}_{3}\right)$, dan sikap $\left(\mathrm{X}_{4}\right)$ dinyatakan valid, maka indikator dalam seluruh variabel dapat digunakan di dalam penelitian.

Tabel 3. Hasil Uji Validitas

\begin{tabular}{ccccc}
\hline Variabel & Indikator & Koefisien Korelasi & Signifikansi & Keterangan \\
\hline \multirow{2}{*}{ Motivasi $\left(X_{1}\right)$} & $X_{1,1}$ & 0,676 & 0,000 & Valid \\
& $X_{1,2}$ & 0,750 & 0,000 & Valid \\
& $X_{1,3}$ & 0,800 & 0,000 & Valid \\
\hline \multirow{2}{*}{ Persepsi $\left(X_{2}\right)$} & $X_{2,1}$ & 0,828 & 0,000 & Valid \\
& $X_{2,2}$ & 0,681 & 0,000 & Valid \\
& $X_{2,3}$ & 0,730 & 0,000 & Valid \\
Pembelajaran $\left(X_{3}\right)$ & $X_{3,1}$ & 0,475 & 0,000 & Valid \\
& $X_{3,2}$ & 0,706 & 0,000 & Valid \\
& $X_{3,3}$ & 0,809 & 0,000 & Valid \\
Sikap $\left(X_{4}\right)$ & $X_{4,1}$ & 0,856 & 0,000 & Valid \\
& $X_{4,2}$ & 0,790 & 0,000 & Valid \\
& $X_{4,3}$ & 0,656 & 0,000 & Valid \\
\hline
\end{tabular}


Hasil Uji Reliabilitas. Uji reliabilitas dilakukan untuk menunjukkan sejauhmana hasil dari pengukuran dengan alat tersebut dapat dipercaya. Hasil pengukuran data (instrument) harus reliable dalam artian harus memiliki tingkat konsistensi dan kemantapan. Uji reliabilitas instrument menggunakan rumus Cronbach's Alpha. Instrument dikatakan valid jika memiliki nilai rellabilitas sebesar $\geq 0,374$. Hasil uji reliabilitas tiap variabel data dapat dilihat pada Tabel 4 .

Tabel 4. Hasil Uji Reliabilitas

\begin{tabular}{clcc}
\hline No. & \multicolumn{1}{c}{ Variabel } & Cronbach's Alpha & Keterangan \\
\hline 1. & Motivasi $\left(\mathrm{X}_{1}\right)$ & 0,547 & Reliable \\
2. & Persepsi $\left(\mathrm{X}_{2}\right)$ & 0,608 & Reliable \\
3. & Pembelajaran $\left(\mathrm{X}_{2}\right)$ & 0,410 & Reliable \\
4. & Sikap $\left(\mathrm{X}_{2}\right)$ & 0,633 & Reliable \\
\hline
\end{tabular}

Tabel 4 menunjukkan hasil uji reliabilitas yang dapat dilihat dari hasil Cronbach's Alpha mulai dari variabel motivasi $\left(\mathrm{X}_{1}\right)$ memiliki nilai rellabillitas sebesar 0,547 , variabel persepsi $\left(\mathrm{X}_{2}\right)$ sebesar 0,608 , variabel pembelajaran $\left(\mathrm{X}_{3}\right)$ sebesar 0,410, variabel sikap $\left(\mathrm{X}_{4}\right)$ sebesar 0,633. Dilihat dari nilai Cronbach's Alpha masing-masing variabel memiliki angka yang $\geq 0,374$, sehingga disimpulkan variabel motivasi $\left(X_{1}\right)$, persepsi $\left(\mathrm{X}_{2}\right)$, pembelajaran $\left(\mathrm{X}_{3}\right)$, dan sikap $\left(\mathrm{X}_{4}\right)$ dinyatakan reliabel dan dapat digunakan dalam penelitian.

Analisis Faktor. Analisis faktor digunakan untuk dapat mengetahui faktor-faktor yang menjadi penentu keputusan pembelian konsumen.

Pemilihan Komponen. Pemilihan komponen yang pertama menggunakan nilai statistik Kaiser-MeyerOklin (KMO). Hasil Uji KMO berdasarkan Tabel 5. tersebut menunjukkan angka 0,677 untuk Uji KMO yang artinya masih memiliki nilai dalam interval 0,5-1,0 berarti analisis faktor yang dilakukan dalam penelitian ini telah memenuhi atau cukup. Nilai Bartlett's Test of Sphericity sebesar 165.698 dengan signifikansi sebesar 0,000 dengan demikian Bartlett's Test of Sphericity memenuhi atau cukup persyaratan karena signifikansi di bawah 0,05 .

Tabel 5. Hasil Uji KMO dan Barlett's test

\begin{tabular}{ccc}
\hline Kaiser-Meyer-Olkin Measure of Sampling Adequacy (KMO) & Bartlett's Test of Sphericity & Sig \\
\hline 0,677 & 165,698 & 0,000 \\
\hline
\end{tabular}

Measure of Sampling Adequacy. Pemilihan komponen yang kedua menggunakan Measure of Sampling Adequacy (MSA) untuk menilai apakah semua sub-variabel yang diukur bisa dijadikan komponen faktor bersama penentu. Measure of Sampling Adequacy (MSA) diukur menggunakan Anti-Image Corellation. Pada Tabel 6 menunjukkan bahwa semua indikator yang digunakan dalam penelitian ini $>0,5$ mulai dari: indikator $X_{1,1}$ Sebesar 0,724, indikator $X_{1,2}$ Sebesar 0,577, indikator $X_{1,3}$ Sebesar 0,767, indikator $X_{2,1}$ Sebesar 0,693, indikator $\mathrm{X}_{2,2}$ Sebesar 0,547, indikator $\mathrm{X}_{2,3}$ Sebesar 0,507, indikator $\mathrm{X}_{3,1}$ Sebesar 0,688, indikator $\mathrm{X}_{3,2}$ Sebesar 0,699 , indikator $X_{3,3}$ Sebesar 0,716, indikator $X_{4,1}$ Sebesar 0,738, indikator $X_{4,2}$ Sebesar 0,742, indikator $X_{4,3}$ Sebesar 0,568. Hasil dari perhitungan menunjukkan semua sub-variabel yang diukur bisa dijadikan komponen faktor bersama penentu karena memiliki Nilai Anti-Image > 0,5.

Penentuan Jumlah Faktor. Pada penelitian ini untuk penentuan jumlah faktor menggunakan prosedur dengan nilai eigen dan plot screen. Hal yang pertama dilihat adalah nilai eigen seperti disajikan pada Tabel 7. Pada proses ekstraksi dihasilkan 4 faktor dari Tabel 7 yang menunjukkan bahwa faktor 1 sampai dengan 4 menghasilkan nilai eigen $>1,0$ yang memiliki artinya ada 4 komponen model dan semua indikator diuji dengan 4 komponen tersebut. Selanjutnya adalah pembentukan komponen matriks, namun sebelumnya nilai eigen akan diuji terlebih dahulu untuk menentukan jumlah faktor. 
Tabel 6. Anti-Image Corellation

\begin{tabular}{ccc}
\hline No & Indikator & MSA \\
\hline 1. & $\mathrm{X}_{1,1}$ & 0,724 \\
2. & $\mathrm{X}_{1,2}$ & 0,577 \\
3. & $\mathrm{X}_{1,3}$ & 0,767 \\
4. & $\mathrm{X}_{2,1}$ & 0,693 \\
5. & $\mathrm{X}_{2,2}$ & 0,547 \\
6. & $\mathrm{X}_{2,3}$ & 0,507 \\
7. & $\mathrm{X}_{3,1}$ & 0,688 \\
8. & $\mathrm{X}_{3,2}$ & 0,699 \\
9. & $\mathrm{X}_{3,3}$ & 0,716 \\
10. & $\mathrm{X}_{4,1}$ & 0,738 \\
11. & $\mathrm{X}_{4,2}$ & 0,742 \\
12. & $\mathrm{X}_{4,3}$ & 0,568 \\
\hline
\end{tabular}

Penjelasan mengenai Extraction sums of squared loadings dan rotation sums of squared loadings dapat dilihat pada Tabel 8. Dari sisi nilai Extraction Sums of Squared Loadings, komponen 1 memberikan variance sebesar 40,685. Komponen 2 memberikan nilai variance sebesar 12,474, dengan nilai kumulatif 53,157. Komponen 3 memberikan nilai variance sebesar 11,4252, dengan nilai kumulatif 64,409. Komponen 4 memberikan nilai variance sebesar 8,470, dengan nilai kumulatif 72,879 .

Tabel 7. Hasil Nilai Eigen

\begin{tabular}{llll}
\hline \multirow{2}{*}{ Component } & \multicolumn{3}{l}{ Initial Eigenvalues } \\
\cline { 2 - 4 } & Total & $\%$ of Variance & Cumulative $\%$ \\
\hline 1. & 4,882 & 40,682 & 40,682 \\
2. & 1,497 & 12,474 & 53,157 \\
3. & 1,350 & 11,252 & 64,409 \\
4. & 1.016 & 8,470 & 72,879 \\
\hline
\end{tabular}

Dari sisi nilai Rotation Sums of Squared Loadings, komponen 1 memberikan variance sebesar 28,705. Komponen 2 memberikan nilai variance sebesar 14,930, dengan nilai kumulatif 43,634. Komponen 3 memberikan nilai variance sebesar 14,779, dengan nilai kumulatif 58,413. Komponen 4 memberikan nilai variance sebesar 14,466, dengan nilai kumulatif 72,879.

Berdasarkan Tabel 8. dapat dilihat nilai dari Cumulative semuanya adalah 72,878 yang didapatkan dari penjumlahan 40,682 +12,474 +11,252 + 8,470 yang memiliki arti bahwa keempat faktor tersebut dapat menjelaskan 72,878\% komponen asal. Setelah analisis nilai eigen maka terbentuklah 4 faktor dan 12 indikator.

Tabel 8. Penentuan Jumlah Faktor

\begin{tabular}{ccccccc}
\hline Component & \multicolumn{3}{c}{ Extraction Sums of Squared Loadings } & \multicolumn{3}{c}{ Rotation Sums of Squared Loadings } \\
\cline { 2 - 6 } & Total & \% of VarianceCumulative \% & Total & $\begin{array}{c}\text { \% of } \\
\text { Variance }\end{array}$ & Cumulative \% \\
\hline 1. & 4,882 & 40,682 & 40,682 & 3,445 & 28,705 & 28,705 \\
2. & 1,497 & 12,474 & 53,157 & 1,792 & 14,930 & 43,634 \\
3. & 1,350 & 11,252 & 64,409 & 1,773 & 14,779 & 58,413 \\
4. & 1,016 & 8,470 & 72879 & 1,736 & 14466 & 72,879 \\
\hline
\end{tabular}


Penggolongan Komponen ke dalam Faktor. (1) Komponen Matriks Sebelum Rotasi. Langkah selanjutnya adalah menggolongkan komponen ke dalam faktor yang telah ditentukan. Setelah mendapat loading faktor, faktor yang akan dipakai dalam analisis ini terdapat 4 faktor, selanjutnya indikator yang mendapatkan nilai > 0,5 akan digolongkan ke dalam komponen tersebut. Adapun komponen matriks sebelum rotasi dapat dilihat pada Tabel 9.

Tabel 9 menunjukan bahwa komponen 1 berkorelasi kuat dengan $\mathrm{X}_{4,2}$ yaitu sebesar 0.812 sehingga indikator dari $\mathrm{X}_{4,2}$ dalam komponen 1 , begitu juga dengan $\mathrm{X}_{1,1}, \mathrm{X}_{1,2}, \mathrm{X}_{1,3}, \mathrm{X}_{2,1}, \mathrm{X}_{2,3}, \mathrm{X}_{3,1}, \mathrm{X}_{3,2} \mathrm{X}_{3,3}$ $\mathrm{X} 4,1$. Pada komponen 2 berkorelasi kuat dengan indikator $X_{4,3}$ yaitu sebesar 0,703. Pada Komponen 3 berkorelasi kuat dengan indikator $\mathrm{X}_{2,2}$ yaitu sebesar 0,596.

Tabel 9. Komponen Matriks Sebelum Rotasi

\begin{tabular}{llll}
\hline \multirow{2}{*}{ Indicator } & \multicolumn{1}{c}{ Component } & 3 & 4 \\
\cline { 2 - 4 } & 1 & & \\
$\mathrm{X}_{1,1}$ & 0,735 & & \\
$\mathrm{X}_{1,2}$ & 0,572 & & \\
$\mathrm{X}_{1,3}$ & 0,802 & 0,596 & \\
$\mathrm{X}_{2,1}$ & 0,651 & & \\
$\mathrm{X}_{2,2}$ & & & \\
$\mathrm{X}_{2,3}$ & 0,548 & & \\
$\mathrm{X}_{3,1}$ & 0,498 & & \\
$\mathrm{X}_{3,2}$ & 0,553 & & \\
$\mathrm{X}_{3,3}$ & 0,606 & & \\
$\mathrm{X}_{4,1}$ & 0,805 & & \\
$\mathrm{X}_{4,2}$ & 0,812 & & \\
$\mathrm{X}_{4,3}$ & & 0,703 & \\
\hline
\end{tabular}

Selanjutnya pada tahap ini akan dilakukan rotasi faktor varimax yang akan bertujuan untuk dapat memperjelas indikator-indikator yang dapat diuji untuk masuk ke dalam empat faktor tersebut. Dilihat pada Tabel 9. indikator rata-rata cenderung ke komponen atau faktor 1, lalu diikuti oleh komponen 2 dan 3 yang memiliki masing-masing satu indikator. Sedangkan pada komponen 4 tidak ada indikator yang saling berkorelasi. Maka untuk pengujian setelah rotasi indikator- indikator tersebut akan menyebar ke dalam empat faktor tersebut. Selanjutnya akan ada pengujian setelah rotasi yang akan di jelaskan pada pembahasan selanjutnya.

Tabel 10. Komunalitas.

\begin{tabular}{ccc}
\hline No & Indikator & Nilai Komunalitas \\
\hline 1. & $\mathrm{X}_{1,1}$ & 0.696 \\
2. & $\mathrm{X}_{1,2}$ & 0.710 \\
3. & $\mathrm{X}_{1,3}$ & 0.849 \\
4. & $\mathrm{X}_{2,1}$ & 0.521 \\
5. & $\mathrm{X}_{2,2}$ & 0.783 \\
6. & $\mathrm{X}_{2,3}$ & 0.824 \\
7. & $\mathrm{X}_{3,1}$ & 0.629 \\
8. & $\mathrm{X}_{3,2}$ & 0.592 \\
9. & $\mathrm{X}_{3,3}$ & 0.814 \\
10. & $\mathrm{X}_{4,1}$ & 0.770 \\
11. & $\mathrm{X}_{4,2}$ & 0.782 \\
12. & $\mathrm{X}_{4,3}$ & 0.774 \\
\hline
\end{tabular}


Komunalitas. Nilai komunalitas haruslah lebih dari 0,5 pada setiap indikator. Hal itu harus terpenuhi untuk dapat dipakai untuk analisis selanjutnya. Berikut nilai komunalitas dari indikator yang diuji dapat dilihat pada Tabel 10. Berdasarkan Tabel 10. Nilai Komunalitas pada setiap indikator memiliki nilai > 0,5 maka tidak adanya indikator yang dikeluarkan, sehingga 12 indikator inilah yang akan digunakan untuk menentukan hasil dari analisis faktor selanjutnya.

Komponen Matriks Setelah Rotasi. Berikut ini adalah hasil dari Komponen Matriks Setelah Rotasi dapat dilihat pada Tabel 11 didapatkan bahwa seluruh komponen saling berkorelasi dengan seluruh faktor yang menjadi indikator. Berdasarkan tabel tersebut diketahui bahwa Komponen 1 berkorelasi kuat pada indikator $\mathrm{X}_{4,1}, \mathrm{X}_{4,2}, \mathrm{X}_{1,3,}, \mathrm{X}_{1,1}, \mathrm{X}_{3,2}$ dan $\mathrm{X}_{2,1}$. Komponen 2 berkorelasi kuat dengan $\mathrm{X}_{4,3}$ dan $\mathrm{X}_{3,3}$. Komponen 3 berkorelasi kuat dengan $\mathrm{X}_{2,2}$ dan $\mathrm{X}_{3,1}$ dan Komponen 4 berkorelasi kuat dengan $\mathrm{X}_{1,2}$ dan $\mathrm{X}_{2,3}$. Rangkuman dari hasil Tabel 11 akan dijelaskan selanjutnya.

Tabel 11. Komponen Matriks Setelah Rotasi

\begin{tabular}{cccc}
\hline Komponen & \multicolumn{3}{c}{ Component } \\
1 & 2 & 3 & 4 \\
\hline $\mathrm{X}_{1,1}$ & 0,797 & & 0,772 \\
$\mathrm{X}_{1,2}$ & & & \\
$\mathrm{X}_{1,3}$ & 0,820 & & \\
$\mathrm{X}_{2,1}$ & 0,508 & 0,849 & \\
$\mathrm{X}_{2,2}$ & & & 0,879 \\
$\mathrm{X}_{2,3}$ & & & \\
$\mathrm{X}_{3,1}$ & & & \\
$\mathrm{X}_{3,2}$ & 0,581 & 0,817 & \\
$\mathrm{X}_{3,3}$ & & & \\
$\mathrm{X}_{4,1}$ & 0,829 & & \\
$\mathrm{X}_{4,2}$ & 0,823 & 0,850 & \\
$\mathrm{X}_{4,3}$ & & & \\
\hline
\end{tabular}

Hasil Analisis Faktor. Berdasarkan Hasil dari Tabel 11 yang rangkumannya akan terkait dengan indikator dari nilai loading factor yang didapatkan oleh masing-masing indikator. Berikut hasil dari analisis faktor pada Tabel 12. Berdasarkan hasil analisis faktor pada Tabel 12 maka dapat disimpulkan sebagai berikut: (1) Faktor 1 mengelompokkan sebanyak 6 indikator yaitu Keyakinan akan hidup sehat karena mengkonsumsi sayuran organik $\left(\mathrm{X}_{1,1}\right)$ dengan loading factor sebesar 0,797 , Tertarik terhadap kualitas sayuran organik $\left(\mathrm{X}_{1,3}\right)$ dengan loading factor Sebesar 0,820, Pengetahuan akan gizi sayuran organik $\left(\mathrm{X}_{2,1}\right)$ dengan loading factor sebesar 0,508, Memperoleh informasi dari pengalaman sendiri $\left(\mathrm{X}_{3,2}\right)$ dengan loading factor sebesar 0,581, Ketertarikan akan membeli sayuran organik $\left(\mathrm{X}_{4,1}\right)$ dengan loading factor sebesar 0,829, Keikutsertaan dalam mensosialisasikan sayuran organik $\left(\mathrm{X}_{4,2}\right)$ dengan loading factor sebesar 0,823; (2) Faktor 2 memiliki dua indikator, meliputi Memperoleh informasi dari orang lain $\left(\mathrm{X}_{3,3}\right)$ dengan loading factor sebesar 0,817, Konsistensi mengkonsumsi sayuran organik $\left(\mathrm{X}_{4,3}\right)$ sebesar 0,850; (3) selanjutnya pada faktor 3 memiliki dua indikator yang meliputi Pengetahuan akan harga sayuran organik yang tinggi $\left(\mathrm{X}_{2,2}\right)$ dengan loading factor sebesar 0,849, Memahami sayuran organik dari media sosial dan media cetak $\left(\mathrm{X}_{3,1}\right)$ dengan loading factor sebesar 0,717 ; (4) Terakhir pada faktor 4 memiliki dua indikator yang meliputi Keinginan untuk menunjukkan status sosial $\left(\mathrm{X}_{1,2}\right)$ dengan loading factor sebesar 0,772,Pemahaman mutu pelayanan lokasi $\left(\mathrm{X}_{2,3}\right)$ dengan loading factor sebesar 0,879 .

Indikator-indikator telah dikelompokkan ke masing-masing faktor yang telah memiliki loading factor lebih dari 0,5. Dengan demikian, seluruh faktor dapat digunakan sebagai hasil dari analisis faktor pada penelitian ini. Langkah selanjutnya adalah faktor-faktor tersebut akan segera diberi nama sesuai dengan nilai yang didapatkan serta akan dijelaskan ke pembahasan selanjutnya. 
Tabel 12. Hasil Analisis Faktor

\begin{tabular}{lll}
\hline Faktor & Indikator & Loading Factor \\
\hline 1. & Keyakinan akan hidup sehat karena mengkonsumsi sayuran organik \\
& $\left(\mathrm{X}_{1,1}\right)$ & 0.797 \\
& Ketertarikan terhadap kualitas sayuran organik $\left(\mathrm{X}_{1,3}\right)$ & 0.820 \\
& Pengetahuan akan gizi sayuran organik $\left(\mathrm{X}_{2,1}\right)$ & 0.508 \\
& Memperoleh informasi dari pengalaman sendiri $\left(\mathrm{X}_{3,2}\right)$ & 0.581 \\
& Ketertarikan akan membeli sayuran organik $\left(\mathrm{X}_{4,1}\right)$ & 0.829 \\
& Keikutsertaan dalam mensosialisasikan sayuran organik $\left(\mathrm{X}_{4,2}\right)$ & 0.823 \\
\hline 2. & Memperoleh informasi dari orang lain $\left(\mathrm{X}_{3,3}\right)$ & 0.817 \\
& Konsistensi mengkonsumsi sayuran organik $\left(\mathrm{X}_{4,3}\right)$ & 0.850 \\
\hline 3. & Pengetahuan akan harga sayuran organik yang tinggi $\left(\mathrm{X}_{2,2}\right)$ & 0.849 \\
& Memahami sayuran organik dari media sosial dan media cetak $\left(\mathrm{X}_{3,1}\right)$ & 0.717 \\
\hline 4. & Keinginan untuk menunjukkan status sosial $\left(\mathrm{X}_{1,2}\right)$ & 0.772 \\
$\quad$ Pemahaman mutu pelayanan lokasi $\left(\mathrm{X}_{2,3}\right)$ & 0.879 \\
\hline
\end{tabular}

(5) Perumusan Faktor Baru. (a) Penamaan Faktor Baru. Berdasarkan pada pengolahan data yang dilakukan, maka terbentuklah empat faktor baru dalam penelitian ini. Nilai dari loading factor pada setiap indikator dalam sebuah fakta yang dapat dilihat pada Tabel 13. Pemberian nama pada faktor baru yang disebut faktor 1,2,3, dan 4 akan diberi nama sesuai dengan loading factor terbesar yang didapatkan oleh indikator pada faktor tersebut. Pemberian nama bagi setiap faktor yang telah terbentuk dilakukan dengan metode sebagai berikut: (1) Pemberian nama pada setiap faktor harus mewakili setiap indikator yang tercakup; (2) Jika terdapat item variabel yang berbeda, maka nilai loading factor tertinggi dalam suatu faktor yang terbentuk dapat menjadi acuan untuk dijadikan sebagai nama faktor; (3) Jika terdapat sebuah kesenjangan yang cukup jauh dalam sebuah faktor, maka pemberian nama tersebut dapat lebih dari satu nama.

Tabel 13. Proses Penamaan faktor Baru

\begin{tabular}{|c|c|c|c|c|}
\hline Factor* & Eigen Value & $\%$ Varians & Indikator & Loading Factor \\
\hline \multirow{6}{*}{1.} & \multirow{6}{*}{4,882} & \multirow{6}{*}{40,682} & $\mathrm{X}_{1,1}$ & 0.797 \\
\hline & & & $\mathrm{X}_{1,3}$ & 0.802 \\
\hline & & & $X_{2,1}$ & 0.508 \\
\hline & & & $\mathrm{X}_{3,2}$ & 0.581 \\
\hline & & & $\mathrm{X}_{4,1}$ & 0.829 \\
\hline & & & $X_{4,2}$ & 0.823 \\
\hline \multirow{2}{*}{2.} & & & $X_{3,3}$ & 0.817 \\
\hline & 1,497 & 12,474 & $\mathrm{X}_{4,3}$ & 0.850 \\
\hline \multirow{2}{*}{3.} & \multirow{2}{*}{1,350} & \multirow{2}{*}{11,252} & $\mathrm{X}_{2,2}$ & 0.849 \\
\hline & & & $X_{3,1}$ & 0.717 \\
\hline \multirow{2}{*}{4.} & \multirow{2}{*}{1,016} & \multirow{2}{*}{8,470} & $\mathrm{X}_{1,2}$ & 0.772 \\
\hline & & & $X_{2,3}$ & 0.879 \\
\hline
\end{tabular}

Keterangan: * urutan nomor menunjukkan peringkat kejadian/kepentingan

Berdasarkan dari Tabel 13, maka faktor-faktor 1, 2, 3, dan 4 diberi nama baru sebagai berikut: Faktor 1 : Sikap, faktor 1 mendapatkan eigen value sebesar 4,882 dengan kontribusi varians 40.682\%. 7 indikator dimiliki oleh faktor 1 yang masing-masing indikator memiliki loading factor sebesar $\geq 0,5$. Pemberian nama faktor sikap berdasarkan dengan loading factor yang terbesar didapatkan oleh indikator Ketertarikan akan membeli sayuran organik $\left(X_{4,1}\right)$ sebesar 0,829 sehingga dapat disesuikan dengan penjelasan awal bahwa $\left(X_{4,1}\right)$ 
adalah bagian dari faktor sikap. Faktor 1 berkaitan dengan teori psikologis yaitu sikap yang dikeluarkan oleh (Kotler dan Keller, 2009) Sikap (attitude), yaitu evaluasi dalam waktu lama tentang yang disukai atau tidak disukai seseorang perasaan emosional, dan kecenderungan tindakan terhadap beberapa objek atau ide. selain dari teori tersebut Ketertarikan juga masuk dalam teori psikologi sosial menurut (Waluya, 2001) yang menyebutkan bahwa Psikologi sosial adalah ilmu pengetahuan yang mempelajari tingkah laku individu sebagai fungsi dari rangsang-rangsang sosial. Individu definisi tersebut menunjukkan bahwa unit analisis dari psikologi sosial adalah individu, bukan masyarakat (seperti dalam sosiologi) maupun kebudayaan (seperti dalam antropologi budaya). Sehingga dari definisi yang singkat tersebut, pengertian psikologi sosial dapat pula diartikan sebagai suatu kajian tentang sifat, fungsi, fenomena perilaku sosial, dan pengalaman mental dari individu dalam sebuah konteks sosial. Diantara fenomena psikologi sosial ini, antara lain kemarahan, perilaku membantu, sikap sosial, ketertarikan dan hubungan sosial, perilaku seksual dan sosialisasi.

Faktor 2 : Konsisten, faktor 2 mendapatkan eigen value sebesar 1.497 dengan kontribusi varians 12.474\%. 2 indikator dimiliki oleh faktor 2 yang masing-masing indikator memiliki loading factor sebesar $\geq$ 0,5. Pemberian nama faktor konsisten berdasarkan dengan loading factor yang terbesar didapatkan oleh indikator Konsistensi mengkonsumsi sayuran organik $\left(\mathrm{X}_{4,3}\right)$ sebesar 0,850 . berdasarkan nilai loading factor terbesar, maka faktor 2 ini beri nama faktor Konsisten. Faktor 2 berkaitan dengan teori Kepribadian, kepribadian adalah sekumpulan sifat psikologi manusia yang menyebabkan respons yang relative konsisten dan tahan lama terhadap rangsangan lingkungan (termasuk perilaku pembelian) seperti diungkap (Kotler dan Keller, 2009) Selain teori tersebut konsisten juga terkait dengan teori stimulus respon yang dikemukkan oleh yaitu Kebiasaan atau habit adalah satu-satunya elemen dalam Teori Dollard dan Miller yang memiliki sifat struktural. Habit adalah ikatan atau asosiasi antara stimulus dengan respon yang relatif stabil dan bertahan lama dalam kepribadian. Gambaran kebiasaan seseorang tergantung pada kejadian khas yang menjadi pengalamannya.

Faktor 3 : persepsi, eigen value yang diperoleh oleh faktor 3 adalah sebesar 1,350 dengan kontribusi varians sebesar 11,252\%. didalam faktor 3 terdapat 2 indikator yang memiliki loading factor $\geq 0,5$. Sedangkan untuk loading factor terbesar adalah Pengetahuan akan harga sayuran organik yang tinggi $\left(\mathrm{X}_{2,2}\right)$ sebesar 0,849 . penjelasan tersebut dapat dijadikan faktor 2 memiliki nama persepsi karena $\left(\mathrm{X}_{2,2}\right)$ merupakan bagian dari faktor persepsi. Faktor 3 berkaitan dengan faktor psikologis yaitu persepsi. Persepsi didefiniskan sebagai proses dimana seseorang memilih, mengorganisasikan dan mengartikan masukan informasi untuk cipatakan suatu gambaran yang berarti dari dunia ini (Kotler dan Keller, 2009).

Faktor 4: Pemahaman, eigen value yang didapatkan oleh faktor 4 adalah sebesar 1.016 dengan kontribusi varians sebesar 8,470\%. Terdapat 2 indikator di dalam faktor 4 yang memiliki loading factor $\geq 0,5$. Loading factor terbesar didapatkan oleh Pemahaman mutu pelayanan lokasi $\left(\mathrm{X}_{2,3}\right)$ dengan loading factor 0,879. karena $\left(\mathrm{X}_{2,3}\right)$ memiliki loading factor terbesar, maka faktor 4 diberi nama faktor pemahaman. Faktor 4 pemahaman berkaitan dengan teori antropologis yang di dalamnya ada faktor budaya. Mempelajari perilaku konsumen adalah mempelajari perilaku manusia, sehingga perilaku konsumen juga ditentukan oleh kebudayaan yang tercemin pada cara hidup, kebiasaan, dan tradisi dalam permintaan akan bermacam-macam barang dan jasa (Sunyoto, 2014). Selain itu hasil ini juga terkait dengan teori pembelajaran (Kotler dan Keller, 2009) yang menyatakan bahwa proses pembelajaran terjadi karena adanya interaksi antara manusia yang dasarnya bersifat individual dengan lingkungan khusus tertentu. Perubahan perilaku seseorang terjual melalui keadaan saling memengaruhi antara dorongan, rangsangan, petunjuk-petunjuk penting jawaban, faktor penguat dan tanggapan.

Berdasarkan hasil yang didapatkan dari survey di lapangan, faktor-faktor yang ada dalam penelitian ini benar adanya pada kondisi dan keadaan responden di lapangan, karena pada saat di lapangan ditemukan responden yang memiliki penampilan yang menunjukkan pendapatan tinggi, berwawasan luas, serta memiliki tubuh yang sehat. Ditemukan juga responden yang tertarik membeli sayuran organik karena telah mengetahui informasi mengenai sayuran organik. Responden yang sudah pernah membeli sayuran organik rata-rata konsisten untuk membeli dengan frekuensi waktu minimal 1 minggu sekali di lokasi pembelian yang sama. 
Walaupun responden mengetahui bahwa sayuran organik memiliki harga yang lebih tinggi, antusias responden untuk membeli masih banyak karena mereka mengetahui kandungan gizi yang dimiliki sayuran organik lebih tinggi dari sayuran non-organik. Responden membeli sayuran organik di lokasi pembelian karena mereka memahami bahwa lokasi pembelian mengetahui cara agar menjaga mutu sayuran organik.

Hasil Uji Validitas dan Uji Reliabilitas Faktor. Uji validitas dan uji reliabilitas dilakukan kembali setelah mendapatkan nilai faktor. Hasil uji validitas dan uji reliabilitas faktor dapat dilihat pada Tabel 13. Loading factor pada Tabel 14 memerlukan nilai uji validitas dengan loading factor $>0,5$ untuk memastikan seluruh faktor dianggap telah valid. Berdasarkan Tabel 13 bahwa semua indikator yang diuji rellabilitas setelah analisis faktor memiliki $\mathrm{h}^{2}$ (rata-rata komunalitas) $\geq 0,3$ yang berarti menandakan bahwa seluruh indikator valid. Nilai Alpha Cronbach pada Tabel 13 menunjukkan bahwa semua faktor memiliki nilai $\geq 0,5$ yang menyatakan bahwa semua indikator yang digunakan telah reliable. Hal itu memiliki arti bahwa pernyataan yang diajukan kepada responden reliable untuk digunakan pada laporan penelitian ini.

Pergeseran Faktor Penentu Keputusan Pembelian Berdasarkan Kajian Teori dan Hasil Penelitian. Penelitian ini mencoba membuktikan kemungkinan terjadinya pergeseran faktor yang menentukan keputusan pembelian. Menurut (Basu S dan Handoko, 1987); (Kotler dan Keller, 2009), faktor yang pertama kali menentukan keputusan pembelian adalah motivasi, diikuti dengan faktor persepsi, pembelajaran dan sikap. Dalam Gambar 3, urutan faktor menunjukkan peringkat kepentingan faktor. Motivasi menjadi faktor pertama, karena berdasarkan teori psiokologi motivasi merupakan perilaku awal penentu konsumen untuk mengkonsumsi, dilanjutkan dengan faktor pembentukan persepsi, pembelajaran, dan perubahan sikap.

Tabel 14. Hasil Uji Validitas dan Uji Reliabilitas Faktor

\begin{tabular}{cccccc}
\hline Faktor & Indikator & Komunalitas & $\mathfrak{h}^{2}$ & $\begin{array}{c}\text { Alpha } \\
\text { Cronbach }\end{array}$ & Keterangan \\
\hline & $\mathrm{X}_{1,1}$ & 0,696 & & & \\
& $\mathrm{X}_{1,3}$ & 0,849 & & & \\
1. & $\mathrm{X}_{2,1}$ & 0,521 & 0,702 & 0,862 & Reliabel \\
& $\mathrm{X}_{3,2}$ & 0,592 & & & \\
& $\mathrm{X}_{4,1}$ & 0,770 & & & \\
& $\mathrm{X}_{4,2}$ & 0,782 & & & Reliabel \\
2. & $\mathrm{X}_{3,3}$ & 0,814 & 0,794 & 0,747 & Reliabel \\
3. & $\mathrm{X}_{4,3}$ & 0,774 & & & Reliabel \\
\hline & $\mathrm{X}_{2,2}$ & 0,783 & 0,706 & 0,627 & \\
\hline
\end{tabular}

Gambar 3 bahwa secara teori, faktor penentu keputusan pembelian adalah adalah motivasi, persepsi, pembelajaran, dan sikap, tetapi hasil analisis menunjukkan hal yang berbeda. Faktor penentu keputusan pembelian adalah pemahaman, konsisten, persepsi, dan sikap. Hasil analisis menunjukkan bahwa dalam hal keputusan pembelian sayuran organik faktor motivasi serta pembelajaran tidak menjadi penentu. Hasil analisis justru memunculkan faktor konsisten dan faktor pemahaman sebagai penentu keputusan pembelian. Selanjutnya untuk mengetahui faktor yang paling berpengaruh, digunakan analisi terhadap Loading faktor. Loading faktor adalah muatan faktor dimana jika faktor memiliki loading faktor paling besar menunjukkan bahwa faktor yang paling berpengaruh, yang memiliki arti juga faktor yang paling penting terlebih dahulu jika dilihat dari kepentingan. Adapun faktor baru yang memiliki loading paling besar sampai terkecil dapat dilihat pada Tabel 15. 


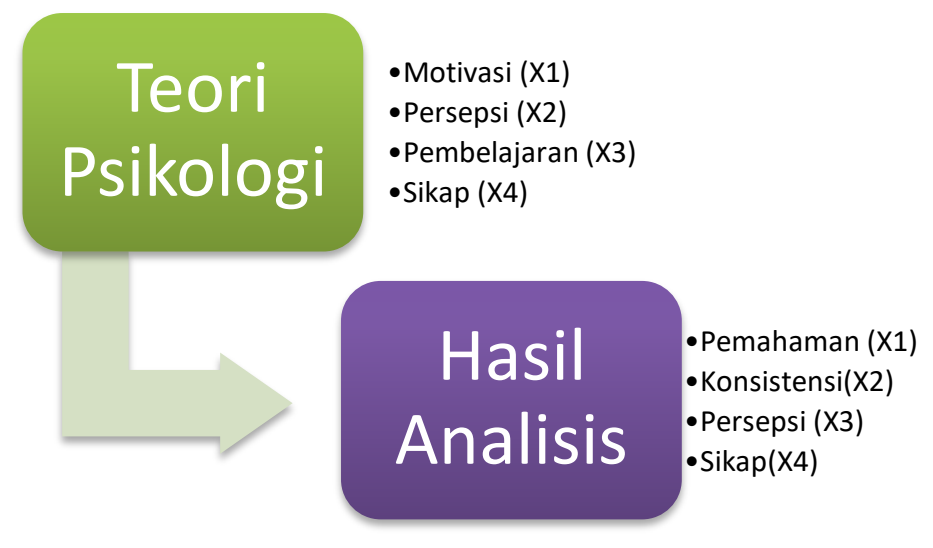

Gambar 3. Pergeseran Faktor Penentu Keputusan Pembelian

Tabel 15 menunjukkan bahwa faktor pemahaman memiliki nilai loading sebesar 0,879 yang berarti faktor pemahaman adalah faktor yang paling mempengaruhi keputusan konsumen dalam pembelian sayuran organik di Pasar Modern Kota Palembang, selanjutnya ada faktor konsisten dengan nilai loading 0,850, selanjutnya faktor persepsi dengan nilai loading 0,849 , dan yang terakhir adalah faktor sikap memiliki nilai loading 0,829. sedangkan dari segi tahapan pelaksanaan atau teori memiliki urutan dari faktor persepsi, pemahaman, sikap dan konsisten.

Tabel 15. Faktor nilai Loading

\begin{tabular}{ll}
\hline Faktor & Nilai Loading \\
\hline Pemahaman & 0,879 \\
Konsisten & 0,850 \\
Persepsi & 0,849 \\
Sikap & 0,829 \\
\hline
\end{tabular}

\section{KESIMPULAN}

Menurut Teori Psikologi, faktor penentu keputusan pembelian adalah motivasi, persepsi, pembelajaran, dan sikap, tetapi hasil analisis menunjukkan hal yang berbeda. Faktor penentu keputusan pembelian adalah pemahaman, konsisten, persepsi, dan sikap. Hasil analisis menunjukkan bahwa dalam hal keputusan pembelian sayuran organik, faktor motivasi serta pembelajaran tidak menjadi penentu. Hasil analisis justru memunculkan faktor konsisten dan faktor pemahaman sebagai penentu keputusan pembelian.

Berdasarkan hasil analisis di atas, maka perusahaan pemasar harus memperhatikan faktor pemahaman karena faktor tersebut terpenting dalam konsumen membeli sayuran organik, baik dari pemahaman pelayanan terhadap sayuran organik dan pemahaman pada pelayanan terhadap konsumen. Selanjutnya, untuk menjaga konsitensi terhadap konsumsi sayuran organik, maka perusahaan pemasar sebaiknya secara berkelanjutan melakukan promosi produk agar tingkat konsumsi konsumen terjaga.

\section{DAFTAR PUSTAKA}

Afandy, T. ., Srikandi, K. . and Fransisca, Y. . (2014) Pengaruh Faktor Psikologis Terhadap Keputusan Pembelian. Malang. Malang.

Ariastuti, N. . and Made, A. . (2008) 'Faktor-faktor Yang Menentukan Loyalitas Pelanggan Terhadap Merek Teh Botol Sosro di Kota Denpasar. Jurnal Agribisnis', Jurnal Agribisnis, Jurusan Sosial Ekonomi Pertanian Fakultas Pertanian Bali: Universitas Udayana.

Arikunto, S. ; (2013) Prosedur Penelitian Suatu Pendekatan Praktik. Jakarta: Rineka Cipta.

Badan Pusat Statistik (2018) Sumatera Selatan dalam Angka. Palembang. 
Basu S, D. H. and Handoko, T. H. . (1987) Manajemen Pemasaran: Analisis perilaku konsumen. Kedua. Edited by BPFE. Yogyakarta.

Deliana, Y. (2012) 'Consumer Preferences on Organic and Anorganic Vegetable in Bandung, West Java, Jawa Barat', Research Journal of Recent Sciences, 1, p. 212-218.

Firdaus, M. ., Harmini; and Farid, M. A. . (2013) Aplikasi Metode Kuantitatif untuk Manajemen dan Bisnis. Bogor: IPB Press.

Ibra, S. (2017) Analisis Perilaku Konsumen Dalam Membeli Cabai Merah Keriting di Pasar Tradisional dan Pasar Modern Kota Palembang. Indralaya: Universitas Sriwijaya.

Jaolis, F. . (2011) 'Profil Green Consumers Indonesia: Identifikasi Segmen dan Faktor- Faktor yang Mempengaruhi Perilaku Pembelian Green Products', Jurnal Mitra Ekonomi dan Manajemen Bisnis, 2(1), pp. 115-136.

Kardinan, A. ; (2016) Sistem Pertanian Organik. Surabaya: Intimedia dan Kelompok Intrans Jawa Timur Publishing.

Kotler, P. . and Keller, K. L. . (2009) Manajemen Pemasaran. Jakarta: Prenhallindo.

Latif, W. A.; (2011) 'Analisis Faktor Psikologis Konsumen dan Pengaruhnya Terhadap Keputusan Pembelian', Jurnal Administrasi Indonesia, 1(1), pp. 23-44.

Muchtadi, D. (2001) Vegetables as Sources of Dietary Fiber to Prevent Degenerative Diseases, Teknologi Pangan dan Gizi, Fat \& IPB. Available at: http://repository.ipb.ac.id (Accessed: 25 August 2017).

Organic Institute;, Yayasan Alifa; and Kombas.id.; (2019) Statistik Pertanian Organik Indonesia. Jakarta: Aliansi Pertanian Indonesia.

Pracaya (2002) Bertanam Sayuran Organik di Kebun, Pot dan Polibeg. Jakarta: Penebar Swadaya.

Rifai, A. ., Didi, M. . and Juwita, R. . (2008) 'Perilaku Konsumen Sayuran Organik di Kota Pekanbaru', Perilaku Konsumen Sayuran Organik di Kota Pekanbaru, XII(21).

Riyanto; and Agus (2012) Penerapan Analisis Multivariat dalam Penelitian Kesehatan. Yogyakarta: Nuha Medika.

Schiffman; and Kanuk; (2008) Perilaku konsumen. 7th edn. Edited by N. Setiadi. Jakarta: Kencana Prenada Media Group.

Suardika, I. M. P., Ambarawati, I. G. and Sukaatmadja, I. P. . (2014) 'Analisis Perilaku Konsumen terhadap Keputusan Pembelian Sayur Organik CV Golden Leaf Farm Bali’, Jurnal Manajemen Agribisnis (Journal Of Agribusiness Management), 2(1), pp. 1-10.

Sunyoto, D. (2014) Praktik Riset Perilaku Konsumen. Edited by R. Sutanto. Yogyakarta: Kanisius.

Sutarni, S. ., Trisnanto, T. B. . and Unteawati, B. . (2017) 'Preferensi Konsumen Terhadap Atribut Produk Sayuran Organik di Kota Bandar Lampung', Jurnal Penelitian Pertanian Terapan, 17(3), pp. 203211. doi: https://doi.org/10.25181/jppt.v17i3.337.

Utari, N. (2014) Perilaku Rumah Tangga dalam Mengkonsumsi Sayuran Organik di Kota Palembang. Indralaya: Universitas Sriwijaya.

Waluya, B. ; (2001) Konsep dasar psikologi. Bandung. 